\title{
Chicle Gum from sapodilla (Manilkara zapota) as a Renewable Resource for Metathesis Transformations
}

\author{
Sonia Reyes-Gómez ${ }^{*}$, Raúl Montiel², Mikhail A. Tlenkopatchev ${ }^{1 * \dagger}$ \\ ${ }^{1}$ Instituto de Investigaciones en Materiales, Universidad Nacional Autónoma de México, Circuito exterior, \\ Ciudad Universitaria, Coyoacán, CP 04510, Ciudad de México, México. \\ ${ }^{2}$ Área de Polímeros, Depto. de Física, DCBI, Universidad Autónoma Metropolitana-Iztapalapa, Av. San \\ Rafael Atlixco No.186, Col. Vicentina, Iztapalapa, CP 09340, Ciudad de México, México. \\ *Corresponding authors: Instituto de Investigaciones en Materiales, Universidad Nacional Autónoma de \\ México, Circuito exterior, Ciudad Universitaria, Coyoacán, CP 04510, Ciudad de México, México. Tel: +52 \\ 5556224586,E-mails: sreyes.mat@comunidad.unam.mx; tma@unam.mx
}

${ }^{\dagger}$ In memory of Dr. Mikhail A. Tlenkopatchev.

Received September 7"th 2017; Accepted December 26 ${ }^{\text {th }}, 2017$.

DOI: $\underline{\text { http://dx.doi.org/10.29356/jmcs.v62i1.581 }}$

\begin{abstract}
In this study, we report on for the first time the self-metathesis of the chicle gum and cross-metathesis of the chicle gum rubber isolated from the gummy latex of sapodilla (Manilkara zapota) with orange oil, $\beta$-pinene and, methyl methacrylate using the Ru-alkylidenes Hoveyda-Grubbs and Grubbs second generation catalysts. There were obtained terpene- and ester-terminated oligoisoprenes, with good yields and selectivities. The present results are a promising starting point for the application of this underexploited renewable resource as a new feedstock for metathesis transformations.
\end{abstract}

Key words: Manilkara zapota; chicle gum; essential oils; metathesis; ruthenium catalysts; oligoisoprenes.

Resumen. En este estudio reportamos por primera vez, la auto-metátesis de la goma de chicle y la metátesis cruzada del hule de la goma de chicle aislada del látex del chicozapote (Manilkara zapota) con aceite de naranja, $\beta$-pineno y metacrilato de metilo, usando los catalizadores Ru-alquilidenos Hoveyda-Grubbs y Grubbs de segunda generación. Se obtuvieron oligoisoprenos con grupos terminales terpeno y éster con buenos rendimientos y selectividades. Los presentes resultados son un punto de partida prometedor para la aplicación de este poco explotado recurso renovable como materia prima para las transformaciones vía metátesis.

Palabras clave: Manilkara zapota; goma de chicle; aceites esenciales; metátesis; catalizadores de rutenio; oligoisoprenos. 


\section{Introduction}

Olefin metathesis, as a technology that allows direct modification of the double bonds of unsaturated natural resources has enormous potential in the transition from petrochemicals to bio-renewable feedstocks [1]. In this perspective, the availability of robust and active catalysts has enabled the metathesis transformations of challenging substrates. The cross-metathesis of natural rubber, butadiene-styrene copolymer, and transpolyisoprene with ethylene (ethenolysis), monoterpenes, triglycerides from plant oils, and functionalized olefins using ruthenium-based catalysts has been carried out resulting in an efficient synthesis of several telechelic oligomers [2-12].

The chicozapote, sapodilla or chicle tree (Manilkara zapota) is one of the species of genus Manilkara belonging to the Sapotaceae family and the Magnoliopsida class. Chemical studies showed the presence of polysaccharides, triterpenes, alkaloids, saponins, tannins, and flavonoids which highlighted the great biological potential of the genus [13-16]. Chicle from the original Maya word sicté [17], has been used for many purposes, such as plantbased drugs in traditional medicine [18], fruit production, and the extraction of the latex sap for use in chewing gum and for the manufacture of adhesives, paints, and varnishes resistant to water, and for insulation in electric conduction cables [19-20]. In addition to being used for seedling [21], the seeds have been considered for biodiesel production due to their oil content of 23-30\% [22].

The sapodilla is a fairly slow-growing, long-lived small to medium evergreen tree, rich in white, gummy latex. This tropical fruit tree is native to Mexico and Central America [18]. It is also cultivated on a large scale in India, Thailand, Cambodia, Malaysia, Indonesia and, Bangladesh mainly for its fruit. In Mexico, the sapodilla is present primarily on the Gulf and Pacific coasts, Chiapas, the Yucatan peninsula and the Great Peten region neighboring Belize and Guatemala, where 1,500 ha are devoted to fruit production (mainly in the states of Campeche and Veracruz), while 4,000 ha are grown primarily for chicle and it is common to find up to 50 adult wild trees/ha [20, 23-24]. The states of Campeche and Quintana Roo are the main producers of certified organic chewing gum, which main demand is from Asia and Italy. The preference for chicle over other sources of natural gum and cheaper synthetic resins is explained by the texture, elasticity, and capacity of chicle to absorb flavors [24].

The trees frequently grow from 15 to $30 \mathrm{~m}$ high and a meter and a half diameter, have a dense wood and take about eight years to mature sufficiently to be tapped for their latex, which is a mixture of terpene-based molecules, such as cis and trans-polyisoprene and pentacyclic triterpenes [17, 25-29]. The quantity of latex that can be derived from a single tree also varies widely, from about three $\mathrm{kg}$ to as much as $15 \mathrm{~kg}$. The trees are tapped during the rainy season (August through January) by itinerant tappers, called chicleros, who locate chicle trees, make zigzag cuts in the bark, and collect the latex exuded. The trees normally bleed for a maximum of $20 \mathrm{~h}$ after tapping incisions are made and are tapped every three or four years [30]. The latex is boiled in an open vessel with constant stirring to reduce the water content to below $40 \%$ obtaining a sticky and elastic consistency. The concentrated latex is then poured into molds to form, on cooling, brown-colored blocks of about eight to $12 \mathrm{~kg}$ each [26]. Since the harvest of trees for timber is prohibited in major tapping regions and the selective extraction of this resource does not affect the diversity of the forest, the harvesting of chicle could play a role in the conservation of the tropical forests and in the sustainable development of rural Latin America [23-24, 31].

A literature review showed that many reports on the characterization of the chicle can be found over the past several decades [15, 17, 25-29, 32-39]. Nevertheless, we are not aware that any work has been performed on the complete characterization of the chicle gum (Manilkara zapota) from the tropical rainforest of the Great Peten in the Yucatan peninsula (Mexico) nor that this renewable resource has been used in metathesis transformations.

In this study, we performed for the first time the self-metathesis of the chicle gum and cross-metathesis of the chicle gum rubber, isolated from the gummy latex of sapodilla (Manilkara zapota) with orange oil, $\beta$-pinene and, methyl methacrylate using the Ru-alkylidenes (1,3-bis-(2,4,6-trimethylphenyl)-2-imidazolidinylidene) dichloro (o-isopropoxyphenyl methylene) ruthenium (Hoveyda-Grubbs catalyst second Generation, HG2) and (1,3bis(2,4,6-trimethylphenyl)-2-imidazolidinylidene) dichloro (phenylmethylene) (tricyclohexylphosphine) ruthenium (Grubbs catalyst second generation, G2). The chicle gum (Manilkara zapota) from the Great Peten tropical rainforest in the Yucatan peninsula (Mexico) and the obtained end-functionalized oligoisoprenes were characterized using the following techniques: (1) wide-angle X-ray scattering (WAXS), (2) thermogravimetric analysis (TGA), (3) differential scanning calorimetry (DSC), (4) nuclear magnetic resonance (NMR), (5) size exclusion chromatography (SEC), (6) matrix-assisted laser desorption/ionization time-of-flight (MALDI-TOF) and (7) gas chromatography mass spectrometry (GC-MS). 


\section{Experimental}

\section{Reagents}

Chicle gum base from the tropical rainforest of the Great Peten in Yucatan peninsula (southeastern Mexico neighboring Belize and Guatemala), tapped from the chicozapote (Manilkara zapota) was purchased from Consorcio Chiclero, SC de RL. Orange oil ( $d$-limonene 96\%, $\beta$-myrcene 4\%) was purchased from 3QR Materias S.A. de C.V. and was used without purification. The (1,3-bis-(2,4,6-trimethylphenyl)-2-imidazolidinylidene) dichloro (o-isopropoxyphenylmethylene) ruthenium (Hoveyda-Grubbs catalyst second Generation, HG2), (1,3bis(2,4,6-trimethylphenyl)-2-imidazolidinylidene) dichloro (phenylmethylene) (tricyclohexylphosphine) ruthenium (Grubbs catalyst second generation, G2), $\beta$-pinene, methyl methacrylate (MMA), toluene anhydrous, tetrahydrofuran HPLC, acetone, ethyl acetate, toluene, methanol and other reagent grade solvents were purchased from Sigma-Aldrich and were used without further purification.

\section{Characterization}

Wide-angle X-ray scattering (WAXS) measurements were carried out in air at room temperature, using a Bruker D-8 Advance diffractometer with the Bragg-Brentano $\theta-\theta$ geometry, $\mathrm{CuK}_{\alpha}$ radiation, a Ni $0.5 \% \mathrm{Cu}-\mathrm{K}_{\beta}$ filter in the secondary beam, and a one-dimensional position-sensitive silicon strip detector (Bruker, Lynxeye). The diffraction intensity as a function of $2 \theta$ angle was measured between $2^{\circ}$ and $30^{\circ}$, with a $2 \theta$ step of $0.02037^{\circ}$, for 0.4 s per point.

Thermogravimetric analysis (TGA) was performed on a TA Instrument (TGA Q5000 IR) with a heating rate $10^{\circ} \mathrm{C} / \mathrm{min}$, under nitrogen, in the range $25-500^{\circ} \mathrm{C}$. The sample weight was about $5 \mathrm{mg}$.

Differential Scanning Calorimeter (DSC) was carried out on a TA Instrument (DSC Q2000). The sealed aluminum pan containing the sample was loaded into the DSC instrument with an identical empty pan used as the reference. The sample weight was $5 \mathrm{mg}$ approximately and it was heated from -88 to $100{ }^{\circ} \mathrm{C}$ at a heating rate of $10^{\circ} \mathrm{C} / \mathrm{min}$.

ATR-FTIR spectra were recorded at room temperature with $4 \mathrm{~cm}^{-1}$ resolution and scanned 32 times on a Nicolet 5700 spectrophotometer with a diamond tip as a dispersing agent.

${ }^{1} \mathrm{H}$ and ${ }^{13} \mathrm{C}$ NMR spectra were recorded on a Varian Inova Unit 300 (300 and $75 \mathrm{MHz}$, respectively) spectrometer. The samples were dissolved in $\mathrm{CDCl}_{3}$. Chemical shifts are reported in ppm downfield from tetramethylsilane $\left(\mathrm{Me}_{4} \mathrm{Si}=0.00 \mathrm{ppm}\right)$.

The number-average molecular weight $(M n)$, the weight-average molecular weight $(M w)$ and molecular weight distributions $(\mathrm{Mw} / \mathrm{Mn})$ were determined by size exclusion chromatography (SEC). The SEC analysis was performed at $35{ }^{\circ} \mathrm{C}$ in THF $(0.3 \mathrm{ml} / \mathrm{min})$ using a Waters ALLIANCE 2695 Separation Module equipped with 2

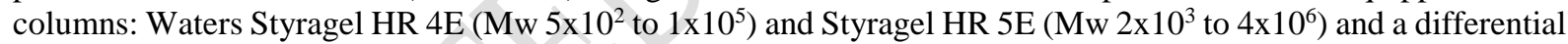
refractometer detector. Narrow molecular weight linear polystyrene (PS) standards (ranging from $3.70 \times 10^{2}$ to $4.290 \times 10^{6}$ ) were used to calibrate the SEC.

The matrix-assisted laser desorption/ionization time-of-flight (MALDI-TOF) mass spectrum was registered on a Bruker Microflex spectrometer equipped with a nitrogen laser $(\lambda=337 \mathrm{~nm})$. The spectrograms were obtained in linear mode with an acceleration tension of $19 \mathrm{kV}$. The irradiation targets were prepared from THF solutions using dithranol and $\mathrm{AgNO}_{3}$ (silver nitrate) as matrix and cationizing agent, respectively.

The GC-MS analysis was carried out using an Agilent Technologies 6890N gas chromatograph with capillary column HP5 (30 m x $0.25 \mathrm{~mm}, 0.25 \mu \mathrm{m}$ film thickness). It was coupled to a JEOL JMS-GC mate II. The temperature was programmed at $40{ }^{\circ} \mathrm{C}$ which was held for a minute and later increased to $310{ }^{\circ} \mathrm{C}$ at a rate of 8 ${ }^{\circ} \mathrm{C} / \mathrm{min}$ for $6 \mathrm{~min}$. The injector was set at $310^{\circ} \mathrm{C}$. Helium was used as a carrier gas with a constant flow of $1 \mathrm{ml} / \mathrm{min}$. The mass spectrometer was operated in electron impact (EI) scan mode at $70 \mathrm{eV}$. Component identification was based on the comparison of retention times and mass spectra with authentic standards. The concentration of pentacyclic triterpenes was estimated by measuring peak areas in ion chromatograms after calculating a correction factor between the peak area on the specific ion chromatogram and the peak area on the total ion current (TIC) chromatogram.

\section{Purification of natural chicle gum}

The chicle gum base or crude chicle was purified following a methodology previously described by Schlesinger and Leeper [26]. The inorganic constituents and carbohydrates were separated from the chicle polymers and resin by dissolving the chicle gum in toluene at $25^{\circ}$ to $35^{\circ} \mathrm{C}$, during $24 \mathrm{~h}$ with constant stirring. This mixture was then centrifuged to separate the transparent yellow-brown toluene solution, i.e., the refined chicle from the brown insoluble (residue). Thereafter, this refined chicle was treated with ethyl acetate and the mixture was refrigerated overnight to precipitate the rubber fraction (CR). This CR was filtered with suction on a Büchner funnel. 
Afterward, it was extracted in a Soxhlet apparatus with acetone for $24 \mathrm{~h}$ to remove waxy and resinous impurities. Subsequently, the trans-1,4-polyisoprene (TPI) extracted was dried in a vacuum oven until the weight was constant. This fraction was used for further analysis. The filtrate obtained by filtering off the CR was treated with acetone in order to precipitate the cis-1,4-polyisoprene (CPI). This polymer was recovered by decanting off the supernatant liquid and was extracted in a Soxhlet with acetone for $24 \mathrm{~h}$. Later, it was dissolved in toluene, filtered through paper, and reprecipitated with acetone. Finally, it was dried under vacuum at room temperature. This CPI was used for further analysis.

The chicle resin was obtained by collecting and concentrating the ethyl acetate-acetone filtrate in a rotavapor. Then, it was dried in vacuo at room temperature. The resin had a yellow appearance and it crystallized spontaneously on standing.

\section{Metathesis procedure}

Self-metathesis of chicle (0.5 g, $1.2 \mathrm{mmol})$ and cross-metathesis of the rubber fraction of chicle (CR) (0.5 g, 7.4 mmol) with chicle resin, orange oil, $\beta$-pinene and, methyl methacrylate (MMA) as CTAs ([C=C]/[CTA]=1:1, 2:1) were performed in toluene anhydrous at $10 \%(\mathrm{w} / \mathrm{v})$, and in bulk conditions, i.e., the solvent was added only with the catalyst. Reactions were warmed to $80{ }^{\circ} \mathrm{C}$ in a preheated, thermostatted oil bath under nitrogen and magnetic stirring for $24 \mathrm{~h}$. The catalyst Hoveyda-Grubbs second generation (HG2) or Grubbs second generation (G2) was added to the reaction vessel in molar ratios $[C=C] /$ catalyst $=100 / 1,200 / 1,500 / 1$ and 1000/1. The metathesis reaction was quenched by adding ethyl vinyl ether, the products were stabilized by adding N-phenyl-1naphthylamine to the solution and then were precipitated using an excess of methanol. The products were dried under vacuum at room temperature and characterized by FT-IR, ${ }^{1} \mathrm{H}$ and ${ }^{13} \mathrm{C}$ NMR, SEC, and MALDI-TOF.

\section{Results and Discussion}

\section{Characterization of the chicle gum (Manilkara zapota) from Yucatan (Mexico)}

To further develop this renewable resource in the field of green chemistry, we needed to determine the structural information in detail. Therefore, the chicle gum was separated into three fractions: the polyisoprenes (TPI and CPI), the resin and the residue. This successful fractionation confirmed that these constituents are not chemically combined but constitute a physical mixture. Each fraction was characterized by wide-angle X-ray scattering. The WAXS diffractograms are shown in Fig. 1 . The CPI shows a broad halo at $2 \theta=20^{\circ}$ which is the signature of the amorphous nature of the sample, whereas TPI is partially crystalline. The interplanar spacing has been calculated using the Bragg's law from which two crystalline phases, namely the $\alpha$ and $\beta$ polymorphic forms were identified [33, 40]. The $\alpha$-form has a monoclinic unit cell with two chains, each containing two repeat units ( $d=7.82,5.52,5.09,4.48,4.28,3.99,3.60,3.31,2.95,2.72 \AA)$. The $\beta$-form has an orthorhombic unit cell with four chains, each containing one repeat unit $(d=4.80,3.86,2.95 \AA)$ [41]. Respect to the resin it presents a crystalline pattern. The peaks of the residue corresponding to the same $2 \theta$ positions of the pure calcium oxalate confirm the presence of calcium oxalate monohydrate as the constituent of the inorganic fraction as Stillwell had reported [33]. 


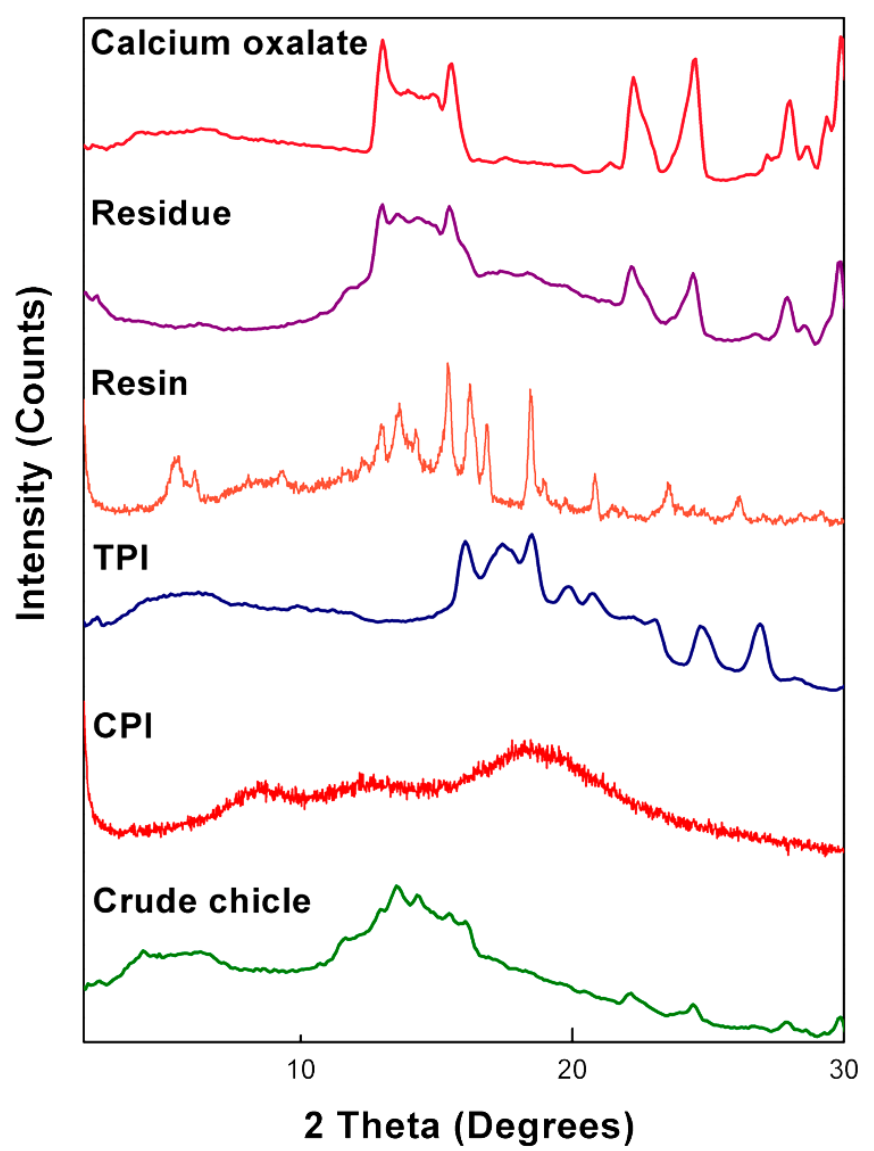

Fig. 1. WAXS diffractograms of chicle gum fractions.

The chicle gum was subjected to thermogravimetric analysis. Fig. 2 shows the TGA/DTG thermograms of the chicle gum. It is observed that the mass loss occurs in three steps. The first step occurs in the range $50-350{ }^{\circ} \mathrm{C}$ with $72.2 \%$ of mass loss and refers to the resin. The second step is observed between $350-438{ }^{\circ} \mathrm{C}$ with $16.5 \%$ of mass loss, which is attributed to the degradation of cis-1,4- and trans-1,4-polyisoprenes. The $11.3 \%$ of residual mass at the end of the thermal degradation process $\left(500^{\circ} \mathrm{C}\right)$ is related to inorganic constituents. This result is in accordance with the chicle gum fractionation procedure.

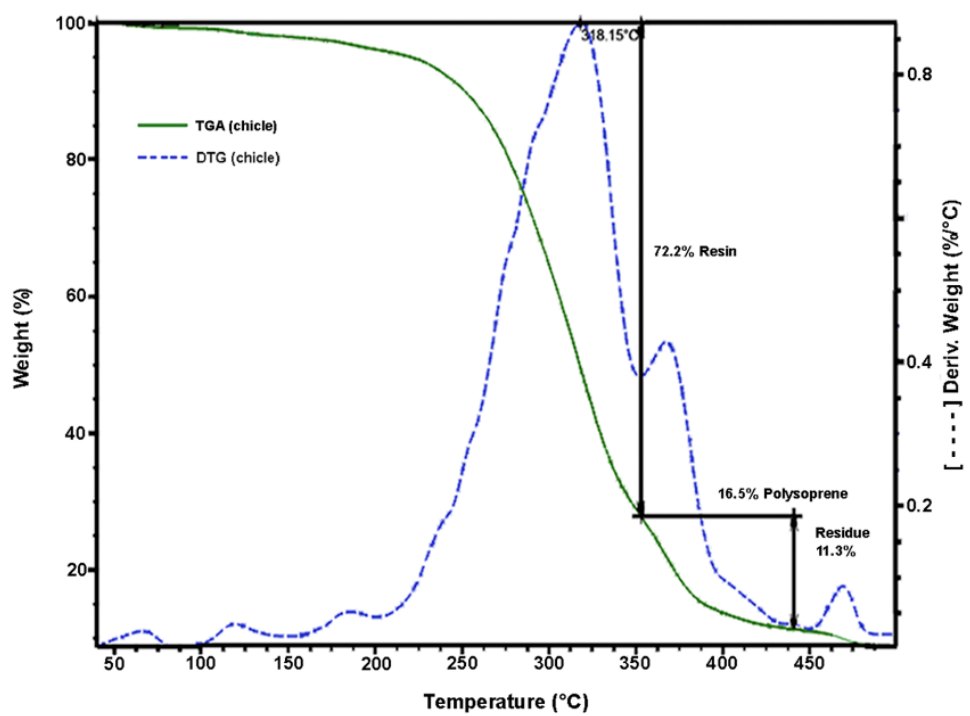

Fig. 2. TGA/DTG thermograms of the chicle gum. 
The rubber fraction of chicle and the isolated TPI and CPI polymers were analyzed through differential scanning calorimetry (DSC), infrared spectroscopy (FT-IR), ${ }^{1} \mathrm{H}$ and ${ }^{13} \mathrm{C}$ nuclear magnetic resonance (NMR) and size exclusion chromatography (SEC). Figures 3a and 3b show the DSC thermograms for TPI and CPI, respectively. The two polymers are very different in physical appearance at room temperature, the trans isomer (TPI) is crystalline and tough, while the cis (CPI) is amorphous and elastic. The Tg for a semi-crystalline polymer such as TPI is broader (and the magnitude of the $\Delta \mathrm{Cp}$ is markedly reduced) than the glass transition observed for the amorphous sample CPI $\left(\mathrm{Tg}=-61.92{ }^{\circ} \mathrm{C}\right)$ [42]. Fig. 3a indicates the presence of both $\alpha$ and $\beta$ forms, as represented by two distinguished peaks $(95.68 \mathrm{~J} / \mathrm{g})$ at $\mathrm{T}_{\text {endo }}=64.92{ }^{\circ} \mathrm{C}$ and $\mathrm{T}_{\text {endo }}=60.67{ }^{\circ} \mathrm{C}$, respectively, with predominantly $\alpha$-form [26, 35, 40]. Whereas in Fig. 3b the peak at $\mathrm{T}_{\text {endo }}=58.29^{\circ} \mathrm{C}$ with a significant difference in the enthalpy value $10.57 \mathrm{~J} / \mathrm{g}$ could be attributed to TPI since a pure cis polymer was not obtained by the fractionation, as can be noticed in the ${ }^{1} \mathrm{H}$ NMR spectrum (Fig. 4c).

a)

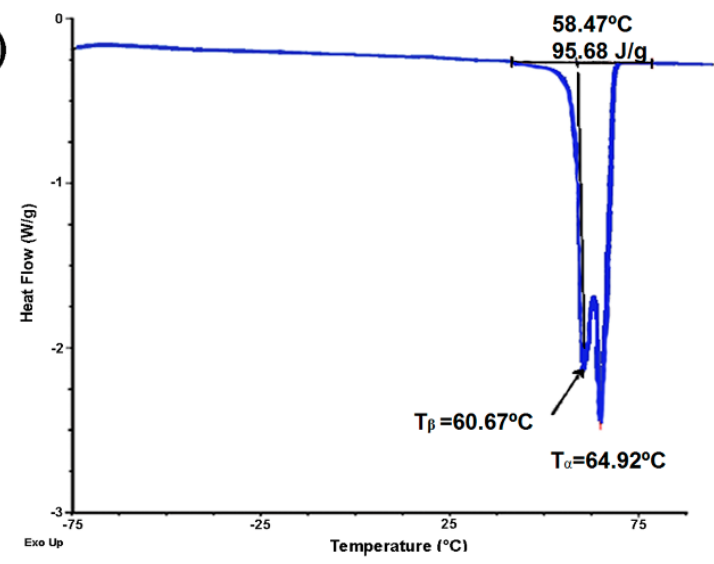

b)

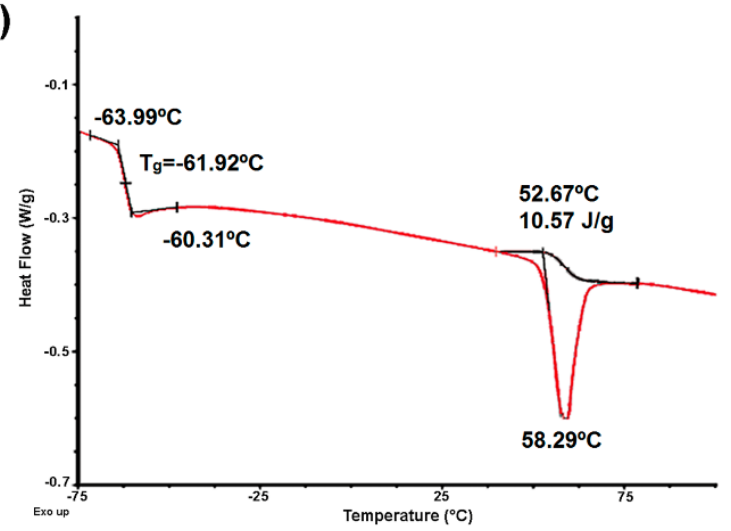

Fig. 3. DSC thermograms of a) TPI and b) CPI.

Additionally, the infrared analysis of TPI and CPI presented characteristic bands of 1,4-units around 836 (CH out-of-plane wagging $\left.\left(-\mathrm{CCH}_{3}=\mathrm{CH}\right)\right), 980\left(\mathrm{C}-\mathrm{CH}_{3}\right.$ stretching), $1446\left(\mathrm{CH}_{2}\right.$ deformation $), 1664(\mathrm{C}=\mathrm{C}$ stretching), 2851 ( $\mathrm{CH}_{2}$ symmetrical stretching), $2912\left(\mathrm{CH}_{2}\right.$ asymmetrical stretching) and $2960\left(\mathrm{CH}_{3}\right.$ asymmetrical stretching) $\mathrm{cm}^{-1}$. Some other specific bands of 1,4-cis units appeared at 572, 742, 1130, and $1315 \mathrm{~cm}^{-1}$. For 1,4-trans units, peaks were observed at $600,801,1152$ and $1325 \mathrm{~cm}^{-1}$. FT-IR also allowed the identification of the bands related to the $\alpha\left(750,1030,1205,1340,2872\right.$, and $\left.2879 \mathrm{~cm}^{-1}\right)$ and $\beta\left(750,997,1212,1348,2906\right.$, and $\left.2914 \mathrm{~cm}^{-1}\right)$ forms of TPI [26, 34, 38, 43].

NMR has been found to be more accurate than the methods based on infrared analysis when determining the cis/trans ratio in polyisoprene mixtures. Accordingly, the relative areas of the methyl proton signals $(\delta=1.67$ and $1.60 \mathrm{ppm}$ for CPI and TPI, respectively) of the isolated chicle rubber were measured and the cis/trans ratio was estimated to be 25/75 [44]. Fig. 4 shows the ${ }^{1} \mathrm{H}$ NMR spectra of chicle gum, TPI and CPI fractions with their corresponding assignments. The ${ }^{13} \mathrm{C}$ NMR of the TPI presents the chemical shifts in $\mathrm{CDCl}_{3} \delta(\mathrm{ppm}): 134.93(\mathrm{C}$ 2), 124.23 (C-3), 39.75 (C-1), 26.73 (C-4), 16.03 (C-5). For CPI $\delta$ (ppm): 135.18 (C-2), 125.0 (C-3), 32.19 (C-1), 26.38 (C-4), 23.42 (C-5). The absence of splitting in C1 and C2 signals from the TPI and CPI spectra indicates that chicle contains both pure cis and trans-PI and constitute merely a physical mixture. These results are in agreement with previous findings [26, 37, 39]. 
c)
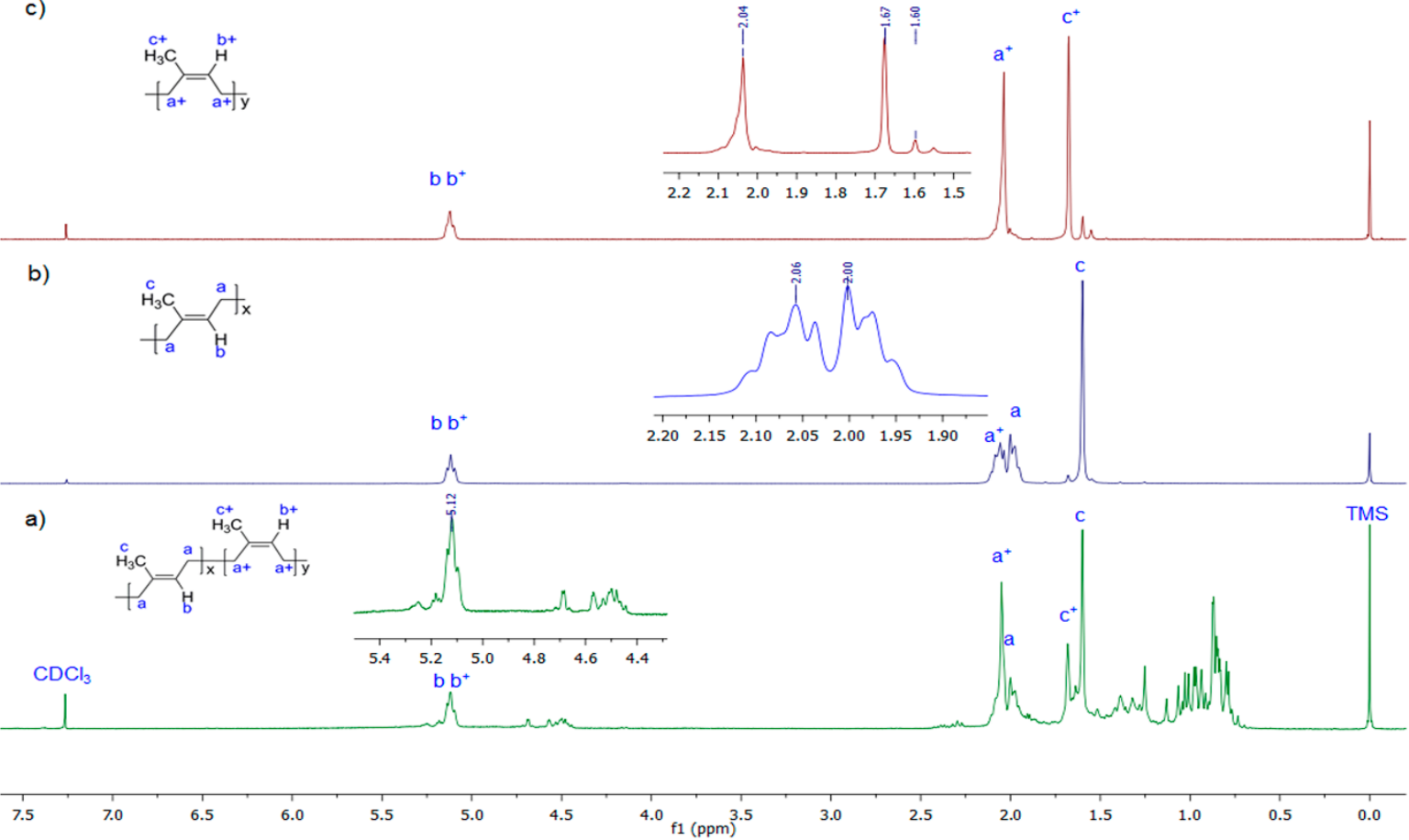

Fig. 4. ${ }^{1} \mathrm{H}$ NMR (300 MHz, $\mathrm{CDCl}_{3}$ ) spectra for a) chicle gum, b) TPI c) CPI fractions.

Fig. 5a presents the SEC chromatograms for the CPI, TPI and refined chicle, i.e., the polymer and resin fractions isolated from the chicle gum. The CPI molecular weight was estimated to be $M n=1.3 \times 10^{5} \mathrm{~g} / \mathrm{mol}$ with a polydispersity of $M w / M n=2.9$ and exhibited a bimodal distribution. It can be noticed that TPI showed a monomodal distribution with $M n=1.5 \times 10^{4} \mathrm{~g} / \mathrm{mol}$ and $M w / M n=1.6$, similar to the molecular weight of the low weight peak of CPI. The molecular weight distribution of the refined chicle is referred to the presence of CPI, TPI and the resin of low molecular weight. Tanaka et al. [39] reported the values of $M n=1.4 \times 10^{5} \mathrm{~g} / \mathrm{mol}$ and $M w / M n=$ 1.3 for CPI, and $M n=7.9 \times 10^{3} \mathrm{~g} / \mathrm{mol}$ and $M w / M n=1.2$ for TPI, using low-angle laser light scattering photometer (LALLS) equipped with a refractive index (RI) detector. Whereas, Hager et al. [27] using an RI detector obtained $M n=1.5 \times 10^{5}$ and $M n \approx 10^{4} \mathrm{~g} / \mathrm{mol}$ for CPI and TPI, respectively. Our results for TPI and CPI could be attributed to the fact that we used the RI detector thus the obtained values were related to PS standards.

One of the key advantages of using MALDI-TOF MS for polymer analysis is that the absolute molecular weights of oligomers can be determined as opposed to obtaining relative molecular weights through chromatographic techniques [45]. Consequently, the chicle gum was analyzed by MALDI-TOF and the spectrum is shown in the Fig. 5b. The sample peaks identified the mass corresponding to the polyisoprene molecules ionized with silver $\left(\mathrm{Ag}^{+}\right)$. The difference between the peaks in the spectrum is equal to the mass of the repeating unit $\left(\mathrm{M}_{\text {isoprene }}=68\right)$. The molecular masses were calculated using the equations reported elsewhere [46], and the values were $M n=7,990, M w=8,373$ and $M w / M n=1.05$. As we were expecting, we obtained a low molecular weight distribution since TPI is the main component of the polymer mixture. In this respect, it has been reported for synthetic trans-1,4-PI that the true $M n$ is actually half the SEC values determined by PS standards [47]. Therefore, our SEC corrected values for the TPI fraction could be in accordance with the $M n$ distribution previously reported $[27,39]$ and with the MALDI-TOF outcome that we obtained. 
a)

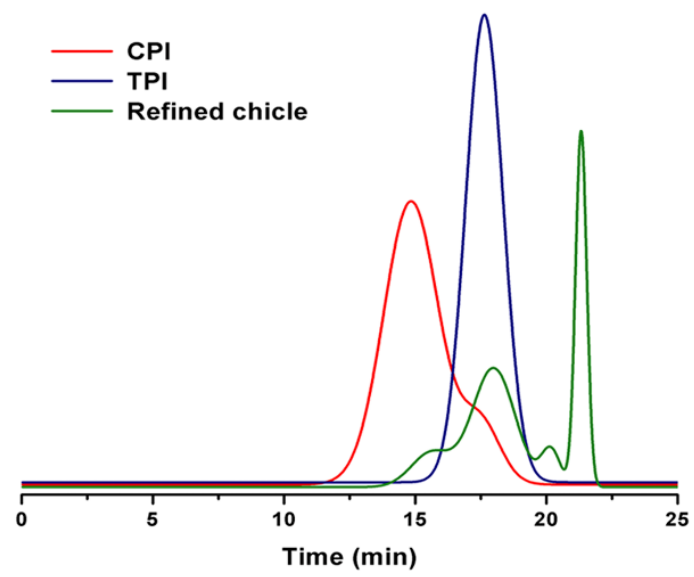

b)

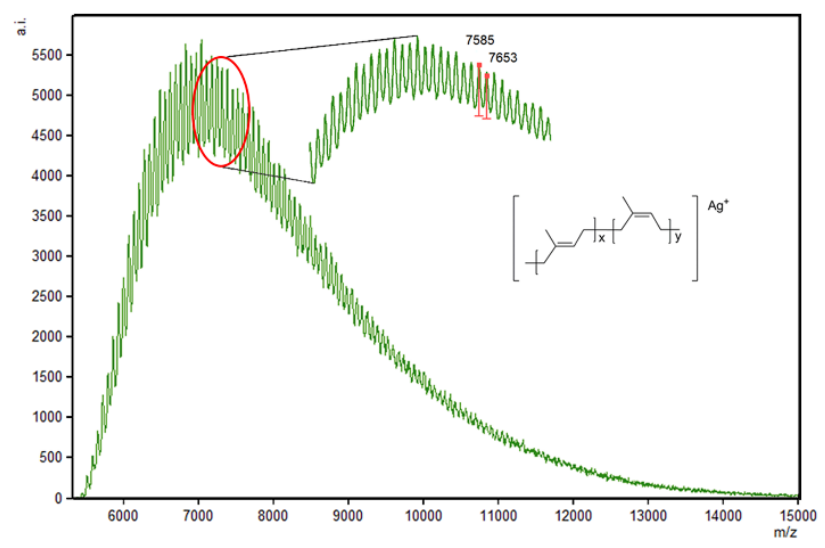

Fig. 5. a) SEC chromatograms of CPI, TPI and refined chicle b) MALDI-TOF MS of chicle gum.

Finally, the chicle resin fraction was analyzed through GC-MS and FT-IR. The GC-MS analysis indicated that four pentacyclic triterpenes eluted in the 33-41 min $t_{R}$ range under our GC conditions (Fig. 6).

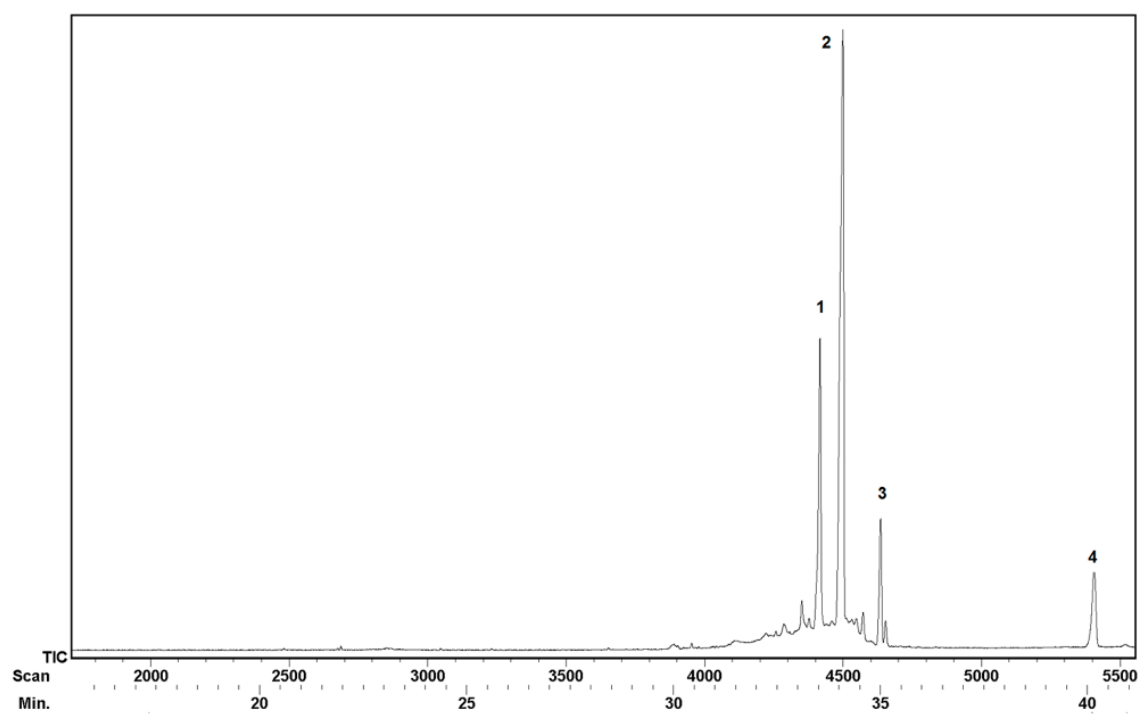

Fig. 6. Gas chromatogram of the chicle resin.

Fig. 7 shows the four pentacyclic triterpenes present in the chicle resin. The identification of the GC peaks was made by comparison of the $t_{R}$ and MS with authentic standards. Our findings are consistent with the previously reported for chicle from Campeche and Guatemala [17, 28-29].

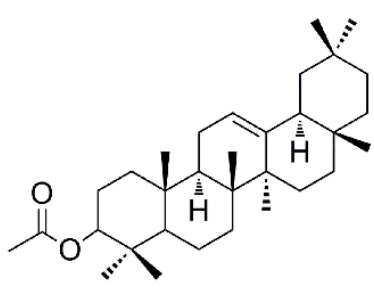

$\beta$-Amyrin acetate $(23.4 \%)$

(1)

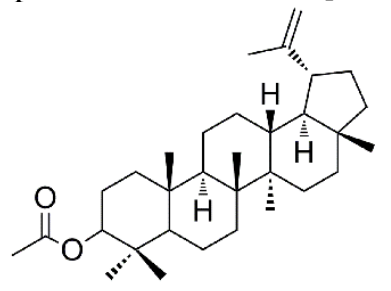

Lupeol acetate

$(59.8 \%)$

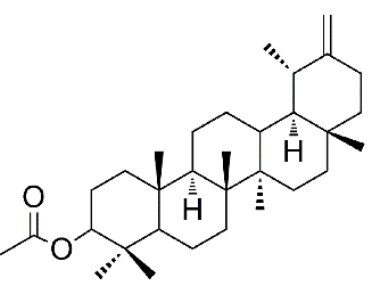

Taraxasterol acetate $(8.34 \%)$

(3)

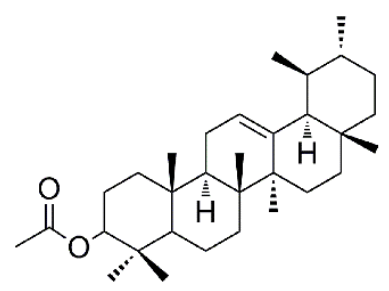

$\alpha$-Amyrin acetate

$(8.5 \%)$

Fig. 7. Structure of compounds 1-4 in chicle resin. Numbers refer to Fig. 6. 
The FT-IR of the chicle resin presents the characteristic bands: 880 (-C= $\left.\mathrm{CH}_{2}\right), 980$ ( $\mathrm{C}-\mathrm{CH}_{3}$ stretching), 1024 $\left(\mathrm{CH}_{3}\right.$ rocking), 1242 (C-O-C asymmetrical stretching), $1362\left(\mathrm{CH}_{3}\right.$ asymmetrical deformation), $1454\left(\mathrm{CH}_{2}\right.$ deformation), 1643 (C=C symmetrical stretching), 1729 (C=O stretching), 2852 ( $\mathrm{CH}_{2}$ symmetrical stretching), $2927\left(\mathrm{CH}_{2}\right.$ asymmetrical stretching), $3063\left(-\mathrm{C}=\mathrm{CH}_{2}\right) \mathrm{cm}^{-1}$.

\section{Metathesis transformations of the chicle gum and chicle rubber fraction (CR)}

Scheme 1 depicts the self-metathesis of chicle and the cross-metathesis of CR with orange oil ( $d$-limonene 96\%), $\beta$-pinene and methyl methacrylate (MMA) as CTAs, catalyzed by the Ru-alkylidenes HG2 and G2 (Fig. 8).

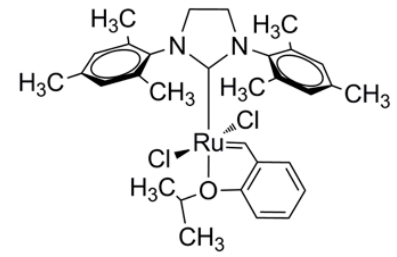

Hoveyda-Grubbs catalyst $2^{\text {nd }}$ generation (HG2)

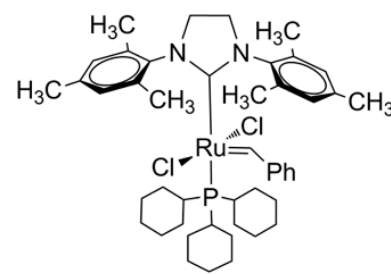

Grubbs catalyst $2^{\text {nd }}$ generation (G2)

Fig. 8. Structures of the HG2 and G2 catalysts used in the metathesis reactions.

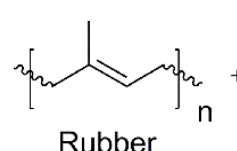<smiles>[R]C=C[R]</smiles>

CTA

(trans-PI, cis-PI)
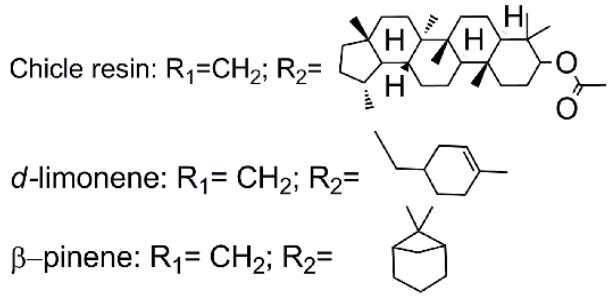

MMA: $\mathrm{R}_{1}=\mathrm{CH}_{2} ; \mathrm{R}_{2}=\mathrm{C}\left(\mathrm{CH}_{3}\right) \mathrm{COOCH}_{3}$

Scheme 1. Self-metathesis of chicle and cross-metathesis of CR with orange oil, $\beta$-pinene and MMA (CTAs) catalyzed by HG2 and G2.

Table 1 summarizes the results of the self-metathesis of chicle (entries 1-2) and cross-metathesis of CR with chicle resin (59.8\% lupeol acetate), orange oil ( $d$-limonene $96 \%), \beta$-pinene and, MMA as CTAs catalyzed by HG2 and G2 (entries 3-9). Reactions were performed in toluene anhydrous at $10 \%(\mathrm{w} / \mathrm{v})$ and in bulk conditions, at $\mathrm{T}=$ $80{ }^{\circ} \mathrm{C}$ for $\mathrm{t}=24 \mathrm{~h}$. In order to prove that the resin was participating as CTA, it was carried out the cross-metathesis of the isolated CR with the chicle resin (entry 3). The catalyst loads (200/1, 1000/1 and, 100/1) permitted the synthesis of the desired ester-terminated oligomers in high yields (79-89\%) and selective manner, as it was confirmed by ${ }^{1} \mathrm{H}$ NMR (Fig. 9). The second-generation catalysts HG2 and G2 (500/1) exhibited high activity in the cross-metathesis reactions of CR with orange oil, $\beta$-pinene and MMA, and afforded the monoterpene and methyl ester end-functionalized oligoisoprenes with high yield (73-93\%) and selectivity. The molar masses $M n$ ranged from 612 to $4,839 \mathrm{~g} / \mathrm{mol}$ and $M w / M n=1.3-2.3$ as it was confirmed by FT-IR, ${ }^{1} \mathrm{H}$ and ${ }^{13} \mathrm{C}$ NMR, SEC and MALDI-TOF (Figures 10-11). The MMA was found a more suitable cross-metathesis partner since it synthesized the semi-telechelic oligomers with the lowest molecular weight compared to the pentacyclic triterpene and monoterpene end-capped products. 
Table 1. Self-metathesis of chicle and cross-metathesis of CR with chicle resin, orange oil, $\beta$-pinene and MMA using HG2 and $\mathrm{G} 2$ as catalysts $\left(\mathrm{T}=80^{\circ} \mathrm{C}, \mathrm{t}=24 \mathrm{~h}\right)$.

\begin{tabular}{ccccccccc}
\hline Entry & Cat. & $\begin{array}{c}\text { C=C/ } \\
\text { Cat. }\end{array}$ & CTA & $\begin{array}{c}\text { Rub./ } \\
\text { CTA }\end{array}$ & $\begin{array}{c}\text { Yield } \\
\text { (\%) }^{\mathbf{a}}\end{array}$ & $\begin{array}{c}\text { Mn } \\
\text { (SEC) }^{\mathbf{b}}\end{array}$ & $\begin{array}{c}\text { Mw } \\
\text { (SEC) }^{\mathbf{b}}\end{array}$ & $\begin{array}{c}\text { Mw/Mn } \\
\text { (SEC) }^{\mathbf{b}}\end{array}$ \\
\hline $\mathbf{1}^{\mathbf{c}}$ & HG2 & $200 / 1$ & - & - & 89 & 2,559 & 3,565 & 1.4 \\
$\mathbf{2}^{\mathbf{d}}$ & HG2 & $1000 / 1$ & - & - & 79 & 3,990 & 5,586 & 1.4 \\
$\mathbf{3}^{\mathbf{e}}$ & HG2 & $100 / 1$ & $\begin{array}{c}\text { Chicle } \\
\text { resin }\end{array}$ & $2: 1$ & 80 & 1,605 & 1,746 & 1.1 \\
$\mathbf{4}$ & HG2 & $500 / 1$ & Orange oil & $1: 1$ & 93 & 4,077 & 6,644 & 1.6 \\
$\mathbf{5}$ & G2 & $500 / 1$ & Orange oil & $1: 1$ & 89 & 4,839 & 7,710 & 1.6 \\
$\mathbf{6}$ & HG2 & $500 / 1$ & $\beta$-pinene & $1: 1$ & 73 & 1,637 & 2,095 & 1.3 \\
$\mathbf{7}$ & G2 & $500 / 1$ & $\beta$-pinene & $1: 1$ & 92 & 2,486 & 5,689 & 2.3 \\
$\mathbf{8}$ & HG2 & $500 / 1$ & MMA & $1: 1$ & 77 & 1,212 & 2,058 & 1.7 \\
$\mathbf{9}$ & G2 & $500 / 1$ & MMA & $1: 1$ & 87 & 612 & 1,398 & 2.2 \\
\hline
\end{tabular}

CR: Chicle rubber fraction: TPI $\left(M n=1.5 \times 10^{4} \mathrm{~g} / \mathrm{mol}, M w / M n=1.6\right)$, CPI $\left(M n=1.3 \times 10^{5} \mathrm{~g} / \mathrm{mol}, M w / M n=2.9\right)$. HG2: Second generation Hoveyda-Grubbs catalyst.

G2: Second generation Grubbs catalyst.

a: Weight percent yield of oligomers.

b: Determined by SEC with THF as the eluent. Values reported relative to PS standards.

c: Chicle gum (72.2\% resin, $12.4 \%$ trans-PI and $4.1 \%$ cis-PI) was dissolved in toluene at concentration $10 \%(\mathrm{w} / \mathrm{v})$.

d: Refined chicle (18.6\% polyisoprenes and $81.4 \%$ resin) was dissolved in toluene at $10 \%(\mathrm{w} / \mathrm{v})$.

e: CR was dissolved in toluene at $10 \%(\mathrm{w} / \mathrm{v})$.

Entries 4-9: Reactions were performed in bulk conditions.

Fig. 9 shows the ${ }^{1} \mathrm{H}$ NMR spectra of a) initial CR and b) after $24 \mathrm{~h}$ of cross-metathesis of CR with chicle resin catalyzed by HG2 (Table 1, entry 3). The initial CR shows chemical shifts at $\delta=5.12(\mathrm{CH}=\mathrm{C}), 2.06,2.00\left(\mathrm{CH}_{2}\right)$, $1.60\left(\mathrm{CH}_{3}\right)$ and a small peak at $1.67 \mathrm{ppm}\left(\mathrm{CH}_{3}\right)$ due to residual CPI. The peak at $\delta=1.25 \mathrm{ppm}$ is referred to residual wax from the resin. Fig. 9b presents the chemical shifts of the pentacyclic triterpene end-capped oligomers. New peaks due to olefin $(\delta=5.25 \mathrm{ppm})$ and vinyl protons appeared at $\delta=4.69$ and $4.68 \mathrm{ppm}$. The methine proton on 3position binding acetyl group is observed at $\delta 4.48 \mathrm{ppm}$. The acetyl group appeared at $2.05 \mathrm{ppm}$ and the presence of methyl signals at $\delta$ ppm: 1.69 (H-30), 1.03 (H-25), 0.94 (H-28), 0.87 (H-23), 0.85 (H-24), $0.84(\mathrm{H}-26)$ and, 0.80 (H-27). The peaks below $2 \mathrm{ppm}$ for aliphatic $\left(\mathrm{CH}_{3}, \mathrm{CH}_{2}\right.$, and $\left.\mathrm{CH}\right)$ were assigned to the pentacyclic triterpene skeleton. The spectra of the products from self-metathesis of chicle and cross-metathesis of CR with chicle resin were identical, thus confirming the selective formation of the ester end-functionalized oligoisoprenes. 


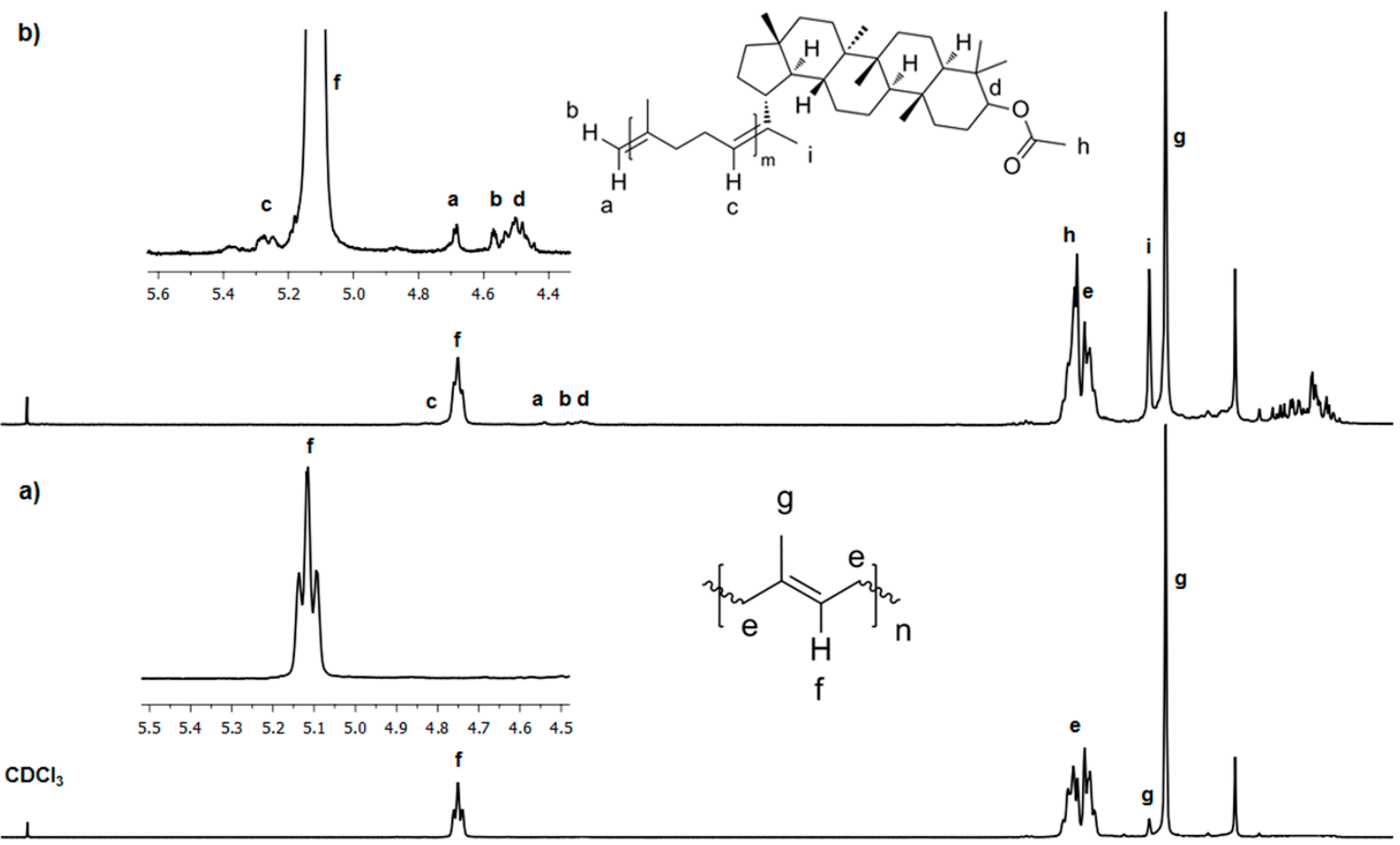

$\begin{array}{lllllllllllllllllllllllllllllllllllll}7.2 & 7.0 & 6.8 & 6.6 & 6.4 & 6.2 & 6.0 & 5.8 & 5.6 & 5.4 & 5.2 & 5.0 & 4.8 & 4.6 & 4.4 & 4.2 & 4.0 & 3.8 & 3.6 & 3.4 & 3.2 & 3.0 & 2.8 & 2.6 & 2.4 & 2.2 & 2.0 & 1.8 & 1.6 & 1.4 & 1.2 & 1.0 & 0.8 & 0.6\end{array}$

Fig. 9. ${ }^{1} \mathrm{H}$ NMR (300 MHz, $\mathrm{CDCl}_{3}$ ) spectra of a) initial CR and b) after $24 \mathrm{~h}$ of cross-metathesis of CR with chicle resin (Table 1 , entry 3 ).

Fig. 10 presents the ${ }^{1} \mathrm{H}$ NMR spectra of CR before and after $24 \mathrm{~h}$ of degradation with orange oil, $\beta$-pinene and, MMA as CTAs catalyzed by HG2 (Table 1, entries 4, 6 and 8). Fig. 10a shows chemical shifts due to TPI and CPI polymers at $\delta=5.12(\mathrm{CH}=\mathrm{C}), 2.06,2.00\left(\mathrm{CH}_{2}\right), 1.67,1.60 \mathrm{ppm}\left(\mathrm{CH}_{3}\right)$. When orange oil (d-limonene 96\%) was used as the cross-metathesis partner, new signals of $\mathrm{C}=\mathrm{CH}$ protons of the cyclic monoterpene appeared at 5.39 ppm. It also showed the signals of $\mathrm{C}=\mathrm{CH}_{2}$ protons at $\delta=4.68$ and $4.70 \mathrm{ppm}$. The signals of the aliphatic protons of $d$-limonene are observed at 1.4-1.1 ppm. For $\beta$-pinene, there were observed new peaks in the $\mathrm{sp}^{2}$ zone at $\delta=$ 5.39, 4.92, 4.70 and $4.68 \mathrm{ppm}$. The protons at $\delta=5.39$ (c*), 4.70 (a) and 4.68 (b) ppm were assigned to the bisvinyl oligomer product; while the signals arising at $\delta=4.92$ (c), 4.70 (a) and 4.68 (b) ppm correspond to the cyclic monoterpene and vinyl terminated product. The peaks in the 1.2-0.9 ppm region were attributed to aliphatic protons of the terpene-terminated oligomer. Finally, when using MMA, the spectrum shows new peaks at $\delta=4.70-4.68$ $\left(\mathrm{C}=\mathrm{CH}_{2}\right)$ and $3.73 \mathrm{ppm}\left(\mathrm{CH}_{3}-\mathrm{OCO}\right)$. These observations confirmed the formation of monoterpene and methyl ester terminated isoprene oligomers. 


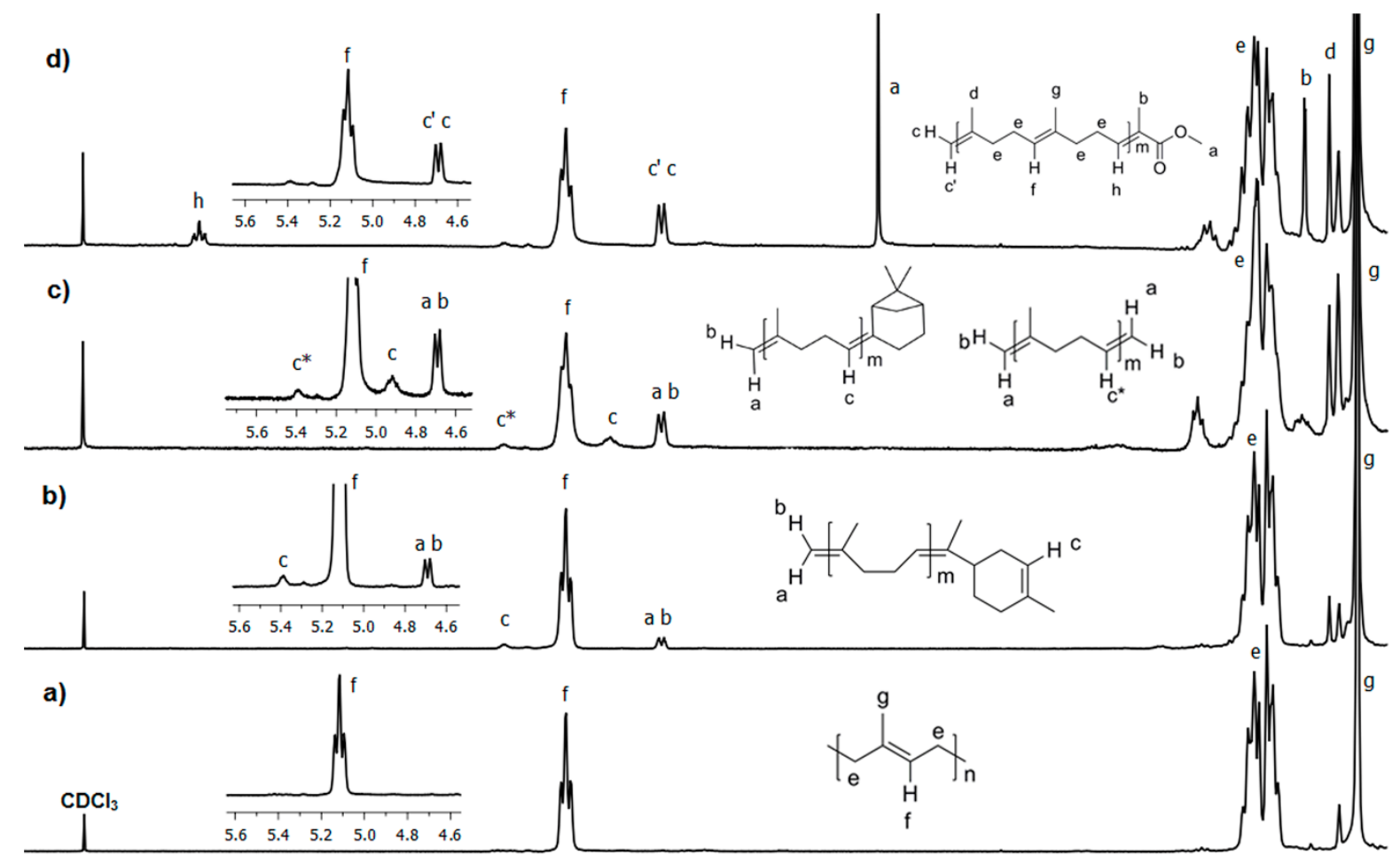

$\begin{array}{lllllllllllllllllllllllllllllll}7.4 & 7.2 & 7.0 & 6.8 & 6.6 & 6.4 & 6.2 & 6.0 & 5.8 & 5.6 & 5.4 & 5.2 & 5.0 & 4.8 & \begin{array}{l}4.6 \\ \mathrm{fi}\end{array}(\mathrm{ppm}) & 4.2 & 4.0 & 3.8 & 3.6 & 3.4 & 3.2 & 3.0 & 2.8 & 2.6 & 2.4 & 2.2 & 2.0 & 1.8 & 1.6\end{array}$

Fig. 10. ${ }^{1} \mathrm{H}$ NMR (300 MHz, $\mathrm{CDCl}_{3}$ ) spectra of a) initial CR and the cross-metathesis products with b) orange oil, c) $\beta$-pinene and d) MMA as CTAs catalyzed by HG2 (Table 1, entries 4, 6 and 8).

The MALDI-TOF MS of the oligomers isolated after precipitation of the cross-metathesis reaction of CR with MMA catalyzed by HG2 is shown in Fig. 11 (Table 1, entry 8). It can be noted that the difference between the main peaks in the spectrum is equal to the mass of isoprene $(M=68)$ as in the case of the chicle gum (Fig. 5b). Two types of products ionized with silver $\left(\mathrm{Ag}^{+}\right)$were identified from the spectrum, the methyl ester endfunctionalized and the macrocycles. The presence of macrocycles could be explained by the intramolecular reaction of the polyisoprene chains [48]. The experimental values are in good agreement with the theoretical masses calculated with the following equation: $M=M($ end group $)+M(A g)+m M($ repeating unit). The molecular mass distribution was estimated to be $M n=438, M w=831$ with a polydispersity of 1.9. While using G2 a higher dispersity was obtained $M n=429, M w=1,715$ and $M w / M n=4.0$. Again, these MALDI-TOF outcomes are lower than those determined by SEC related to PS (Table 1, entries 8 and 9). 

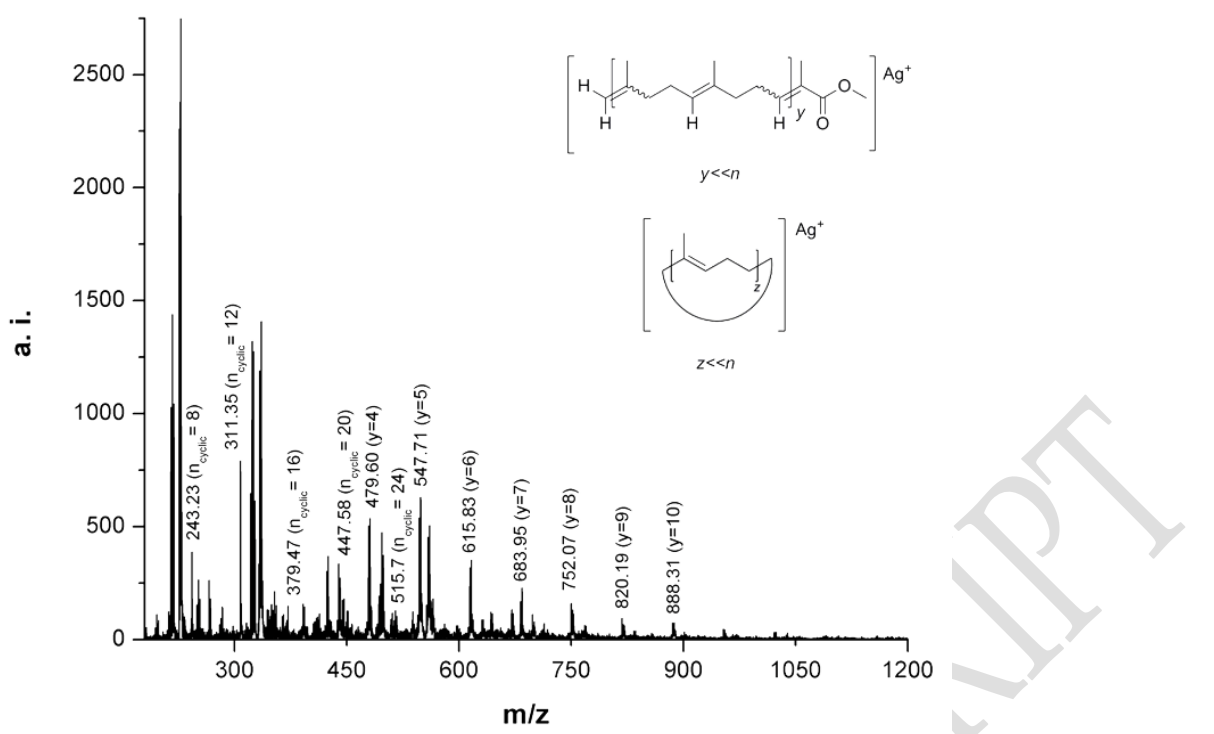

Fig. 11. MALDI-TOF MS of the oligoisoprene products after cross-metathesis of CR with MMA (Table 1, entry 8).

\section{Conclusions}

We studied for the first time, the self-metathesis of the chicle gum and cross-metathesis of the chicle gum rubber isolated from the gummy latex of sapodilla (Manilkara zapota) with orange oil, $\beta$-pinene and methyl methacrylate using the Ru-alkylidenes Hoveyda-Grubbs and Grubbs second generation catalysts. The chicle rubber can undergo efficient cleavage reactions with the resin (59.8\% lupeol acetate) yielding ester-terminated oligoisoprenes, demonstrating that the pentacyclic triterpenes participate as cross-metathesis partners. The secondgeneration catalysts HG2 and G2 exhibited high activity toward the self-metathesis of chicle and cross-metathesis of chicle rubber to give terpene- and ester- end-capped oligomers with good yields (73-93\%) and selectivity. Methyl methacrylate was found a more suitable cross-metathesis co-reactant since it afforded products with the lowest molecular weight compared to those obtained when orange oil and $\beta$-pinene were used as a CTA. We believe that chicle has great potential as a renewable feedstock for the synthesis of telechelic oligomers and polymers.

\section{Acknowledgments}

This work was supported by CONACYT under Grant 214176/14 and the Ph.D. Scholarship to Sonia ReyesGómez. The authors thank Alejandrina Acosta, Gerardo Cedillo, Adriana Tejeda, Salvador López, Damaris Cabrera, Javier Pérez and, Lucero Ríos for their assistance in NMR, SEC, TGA, DSC, GC-MS and, MALDI-TOF measurements.

\section{References}

1. Lummiss, J. A. M., Oliveira, K. C., Pranckevicius, A. M. T., Santos, A. G., Dos Santos, E. N., Fogg, D. E. J. Am. Chem. Soc. 2012, 134, 18889-18891 DOI: http://dx.doi.org/10.1021/ja310054d.

2. Gutierras, S., Martínez Vargas, S., Tlenkopatchev, M. A. Polym. Degrad. Stab. 2004, 83, 149-156 DOI: https://dx.doi.org/10.1016/S0141-3910(03)00247-7.

3. Wolf, S., Plenio, H. Green Chem. 2011, 13, 2008-2012 DOI: https://dx.doi.org/10.1039/C1GC15265C.

4. $\quad$ Ouardad, S., Peruch, F. Polym. Degrad. Stab. 2014, 99, 249-253 DOI:

http://dx.doi.org/10.1016/j.polymdegradstab.2013.10.022.

5. Gutiérrez, S., Tlenkopatchev, M. A. Polym. Bull. 2010, 66, 1029-1038 DOI:

http://dx.doi.org/10.1007/s00289-010-0330-x.

6. Martínez, A., Gutiérrez, S., Tlenkopatchev, M. A. Molecules 2012, 17, 6001-6010 DOI: http://dx.doi.org/10.3390/molecules17056001.

7. Martínez, A., Clark-Tapia, R., Gutiérrez, S., Tlenkopatchev, M. A. Lett. Org. Chem. 2014, 11, 748-754 DOI: https://dx.doi.org/10.2174/157017861110141117143729.

8. Martínez, A., Zúñiga-Villarreal, N., Gutiérrez, S., Tlenkopatchev, M. A. Curr. Org. Synth. 2016, 13, 876-882 DOI: https://dx.doi.org/10.2174/1570179413666151218203008. 
9. $\quad$ Martínez. A., Gutiérrez, S., Tlenkopatchev, M. A., in: Natural Rubber Properties, behavior and applications, Vol. 1, Hamilton, J. L., Ed., Nova Science Publishers, Inc., New York, 2016, 165-191.

10. Tlenkopatchev, M. A., Gutiérrez, S. Química Sostenible. Metátesis de Hules y Aceites Naturales. Metátesis sostenible. EAE Academia Española, Ed. 2013.

11. Gutiérrez, S., Tlenkopatchev, M. A. Supl. la Rev. Latinoam. Metal. y Mater. 2009, 1, 1463-1467.

12. Mouawia, A., Nourry, A., Gaumont, A.-C., Pilard, J.-F., Dez, I. ACS Sustainable Chem. Eng. 2017, 5, 696-700 DOI: http://dx.doi.org/10.1021/acssuschemeng.6b01777.

13. Hart, N. K., Lamberton, J. A., Triffett, A. C. K. Aust. J. Chem. 1973, 26, 1827-1829 DOI: http://dx.doi.org/10.1071/CH9731827.

14. Misra, G., Mitra, C. R. Phytochemistry 1969, 8, 249-252 DOI: http://dx.doi.org/10.1016/S00319422(00)85821-5.

15. Dutton, G. G. S., Kabir, S. Carbohydr. Res. 1973, 28, 187-200 DOI: http://dx.doi.org/10.1016/S00086215(00)82775-5.

16. Islam, M. R., Parvin, M. S., Banu, M. R., Jahan, N., Das, N., Islam, M. E. Int. J. Pharma Sci. 2013, 3, 394-397.

17. Azpeitia, E., Bowers, A., Crabbé, P., Mancera, O., Matthews, J. S., Reynoso, J., Salazar, J. Can. J. Chem. 1961, 39, 2321-2323 DOI: http://dx.doi.org/10.1139/v61-308.

18. Morton, J., in: Fruits of warm climates, Morton, J. F., Ed., Miami, 1987, 393-398.

19. Woodson, R. E., Schery, R. W., Blakwell, W. H. Ann. Mo. Bot. Gard. 1968, 55, 145-169 DOI: http://dx.doi.org/10.2307/2394876.

20. Barrance, J., Beer, D. H., Boshier, J., Chamberlain, J., Cordero, G., Dethefsen, B., Finegan, G., Galloway, M., Gómez, J., Gordon, M., Hands, J., Hellin, C., Hughes, M., Ibrahim, D., Kass, R., Leakey, F., Mesén, M., Montero, C., Rivas, E., Somarriba, J., Stewart, Pennington, T. Árboles de Centroamérica: Un manual para extensionistas. Oxford Forestry Institute - CATIE, Ed. Turrialba, 2003.

21. García Pérez, M. A., Orantes García, C., Miceli Méndez, C. L., Garrido Ramírez, E. R., Pérez López, R. Lacandonia 2010, 4, 17-22.

22. $\quad$ Sathish Kumar, R., Sureshkumar, K., Velraj, R. Fuel 2015, 140, 90-96 DOI:

http://dx.doi.org/10.1016/j.fuel.2014.09.103.

23. Larson J., Sarukhán, J. Gaceta Ecológica 2003, 67, 7-26.

24. Forero O. A., Redclift, M. R. Dev. Pract. 2007, 17, 196-207 DOI:

http://dx.doi.org/10.1080/09614520701195907.

25. Schlesinger W., Leeper, H. M. Science 1950, 112, 51-52 DOI:

http://dx.doi.org/10.1126/science.112.2898.51.

26. Schlesinger, W., Leeper, H. M. Ind. Eng. Chem. 1951, 43, 398-403 DOI:

http://dx.doi.org/10.1021/ie50494a034.

27. Hager, T., MacArthur, A., McIntyre, D., Seeger, R. Rubber Chem. Technol. 1979, 52, $693-709$ DOI: http://dx.doi.org/10.5254/1.3535234.

28. Tezuka, S., Yamano, T., Shitou, T. Nippon Shokuhin Kogyo Gakkaishi 1980, 27, 419-425 DOI: http://dx.doi.org/10.3136/nskkk1962.27.9_419.

29. Sato, Y., Hasegawa, S., Ohtsu, T., Takiguchi, T., Suzuki, Y., Shibata, M. Nippon Shokuhin Kogyo Gakkaishi 1991, 38, 595-600 DOI: http://dx.doi.org/10.3136/nskkk1962.38.595.

30. Barlow, F. W., in: Nat. Prod. Woody Plants, Rowe, J. W., Ed., Springer-Verlag Berlin Heidelberg, 1989, 1028-1050 DOI: http://dx.doi.org/10.1007/978-3-642-74075-6_29.

31. Primack, R. B., Bray, D. B., Galletti, H. A., Ponciano, I. Eds. Timber, tourists, and temples: conservation and development in the Maya Forest of Belize, Guatemala, and Mexico. Island Press, Ed. Washington D. C., 1998.

32. Dannerth, F. J. Ind. Eng. Chem. 1917, 9, 679-682 DOI: http://dx.doi.org/10.1021/ie50091a022.

33. Stillwell, C. W. Ind. Eng. Chem. 1931, 23, 6, 703-706 DOI: http://dx.doi.org/10.1021/ie50258a027.

34. $\quad$ Saunders, R. A., Smith, D. C. J. Appl. Phys. 1949, 20, 953-965 DOI:

http://dx.doi.org/10.1063/1.1698259.

35. Schlesinger, W., Leeper, H. M. J. Polym. Sci. 1953, 11, 203-213 DOI:

http://dx.doi.org/10.1002/pol.1953.120110302.

36. Tanaka, Y., Sato, H., Seimiya, T. Polym. J. 1975, 7, 264-266 DOI:

http://dx.doi.org/10.1295/polymj.7.264.

37. Tanaka, Y., Sato, H. Polymer 1976, 17, 113-116 DOI: http://dx.doi.org/10.1016/0032-3861(76)90078-

38. Kishore, K., Pandey, H. K. Prog. Polym. Sci. 1986, 12, 155-178 DOI: http://dx.doi.org/10.1016/00796700(86)90008-0. 
39. Tanaka, Y., Nunogaki, K., Kageyu, A., Mori, M. Sato, Y. J. Nat. Rubber Res. 1988, 3, 177-183.

40. Ratri P. J., Tashiro, K. Polym. J. 2013, 45, 1019-1026 DOI: http://dx.doi.org/10.1038/pj.2013.31.

41. $\quad$ Ratri, P. J., Tashiro, K., Iguchi, M. Polymer 2012, 53, 3548-3558 DOI:

http://dx.doi.org/10.1016/j.polymer.2012.06.003.

42. $\quad$ Burfield, D. R., Lim, K.-L. Macromolecules 1983, 16, 1170-1175 DOI:

http://dx.doi.org/10.1021/ma00241a024.

43. Pathak, A., Saxena, V., Tandon, P., Gupta, V. D. Polymer 2006, 47, 5154-5160 DOI:

http://dx.doi.org/10.1016/j.polymer.2006.04.067.

44. Golub, M. A., Fuqua, S. A., Bhacca, N. S. J. Am. Chem. Soc. 1962, 84, 24, 4981-4982 DOI: http://dx.doi.org/10.1021/ja00883a073.

45. Yalcin, T., Schriemer, D. C., Li, L. J. Am. Soc. Mass Spectrom. 1997, 8, 1220-1229 DOI: http://dx.doi.org/10.1016/S1044-0305(97)00192-X.

46. $\quad$ Nagahata, R., Shimada, K., Kishine, K., Sato, H., Matsuyama, S., Togashi, H., Kinugasa, S. Int. J. Mass Spectrom. 2007, 263, 213-221 DOI: http://dx.doi.org/10.1016/j.ijms.2007.02.006.

47. Zinck, P., Terrier, M., Mortreux, A. Visseaux, M. Polym. Test. 2009, 28, 106-108 DOI: http://dx.doi.org/10.1016/j.polymertesting.2008.09.010.

48. Tlenkopatchev, M. A., Barcenas, A. Fomine, S. Macromol. Theory Simulations 2001, 10, 441-446 DOI: http://dx.doi.org/10.1002/1521-3919(20010901)10:7<729::AID-MATS729>3.0.CO;2-Q. 